\title{
ショウジョウバエの雄を殺す sex-ratio（SR）因子
}

坂口文 吾

九州大学農学部
一般に有性生殖をする生物の性比は 1:1 であるが, 自然界には性比の著しい不均衡を生ずる場合が少なから ず存在する. ショウジョウバェの“雌をうむ雌” (abnormal sex-ratio または略して SR) と名づける系統も その 1 例である.この系統には, 染色体上の遺伝子によ って支配される場合と, 細胞質因子による場合とが知ら れている. 細胞質因子のはたらきによって雌ばかりをう むショウジョウバェの系統は, 今から約 15 年前に東京 都立大学の森脇教授らとイタリーの Magni によって, 野外から採集したフタスジショウジョウバェ（Drososhila bifasciata) といら種類のハェの中から発見された のが最初である.このハエの特徴は，(1) この SR 系統 のハェに, D.bifasciata の正常の雌雄 1:1 をうむいろ いろな系統の雄を交配しても, 雌ばかりをらむ特性は失 われない; (2) この系統の雌が雄をうむ率は, 雌 1 万匹 に雄はわずか数匹で非常に少なく，この稀にうまれる雄 は SR の特性を子孫に伝えない;（3）SR 雌のうんだ受 精卵の孵化率は約 50\% で, 雄は胚子発生の初期に卵内 で死ぬ；などが挙げられる．このような SR の特性をる ったショウジョウバェは, その後世界の各地で, いろい ろな種類が発見され, 現在までに約 7 種が記載されてい る.これらはいずれも雄が胚子期で死に，雌のみが成虫 となり,このような特性は卵の細胞質を通じて子孫に伝 わり，いわゆる細胞質遺伝をする点で共通している.

最近の細胞質遺伝因子の研究は, 微生物, 原生動物, あるいは高等動植物などを用いて行なわれているが，多 くの場合，この因子の本態は細胞核中に含まれる DNA とは異なった塩基組成からなる DNA をもち, 自己増殖 性のものであることがわかってきた. ショウジョウバェ の細胞質遺伝単位である SR 因子も自己増殖をすると いらことが，注射実験で明らかになった，すなわち，シ ョウジョウバェの SR 系統の雌成虫の体液, 拈よび卵巣,
脂肪組織などの磨砕液を, $\mathrm{SR}$ 系統と同種または異種の 性比 1:1をうむ系統の雌成虫に注射してやると, この 八ェからうまれる子バェの性比は最初 1:1 であるが, しだいに雄の数を減じ, 注射約 1 週間後にうまれる子バ エはついに雌ばかりとなる，このような雌と正常系統の 雄とを交配し, さらに後代を調べると，その子孫は雌の 子バェのみをらむ性質に変わっている. これらのこと は, SR 因子が感染性であり,さらに自己増殖をし, 卵 を通して後代に伝わってゆくことを示している（図）. しかし，SR 因子の感染性と宿主による後代への伝達 性は, SR 因子の種類のちがい, あるいは宿主ハエの遺 伝子構成によって異なり, 遺伝的に感染力の強い SR 因 子と, この因子に感受性の高いハェとを組み合わせると， 安定して後代に伝わり, 雌の子バェのみをらむ状態が保 持される. また, 感染力の弱い SR 因子と, この因子が 増殖しにくいハエの系統とを組み合わせると， SR 因子 は数代後に宿主ハェから消失し,この系のハエは全部正 常にもどる.

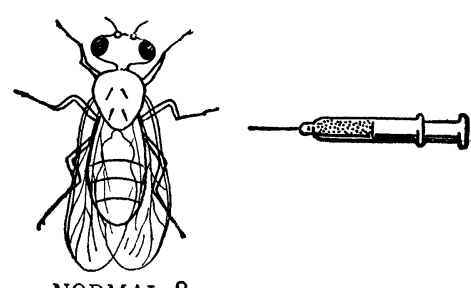

NORMAL 우

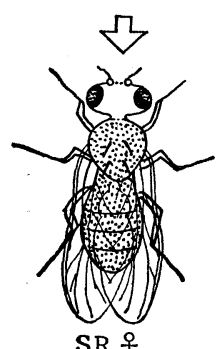

$\mathrm{SR}$ 우

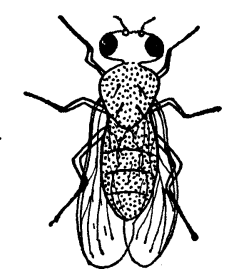

$\mathrm{SR}$ 우

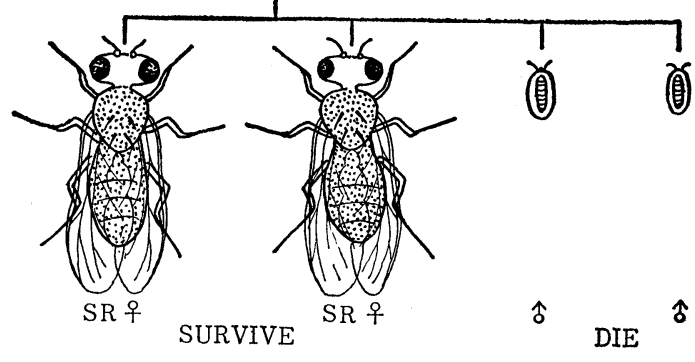

ショウショョヴェの SR 系統のハエの体液を正常のハエ に注射して，このハエをSR 変え，さらにその性質が子 孫に伝えられることを示す. SR 因子をもったハエからう まれる雄は胚子発生途上で死ぬ。 
前述したように，ショウジョウバェの SR 因子は SR 系統の雌バェの体内に存在し, 感 染性を示す単位であることがわかったので， この雌バェの体液をとって, 光学顕微鏡や電 子顕微鏡で調べてみると, プエルトリュ産 equinoxialis, 、イチ産 nebulosa, ジャマイ 力産 willistoni の各種の $\mathrm{SR}$ 系統には, それ らの正常系統の体液中にはみられない長さ約 $10 \mu$, 幅約 $0.1 \mu$ の繊維状のスピロヘータ 類似の微生物がたくさん発見された (写真).

これを位相差顕微鏡で観察すると，規則正 しいピッチをもったらせんの形態を示し，活 発に運動している.この微生物は Giemsa 染 色, basic protein のための Fast Green, リボ核酸のための Azure B などによく染を り, Feulgen 反応山るいはスピロヘータの染 色に用いられる Fontana の銀反応に対して, いずれも陽性である. 以上の形態的特徵や各 種染色剂比する反応から, この微生物はス ピロヘータに属する Treponema あるいは Borrelia 飞近いものと思われる. しかし，こ れを詳紼淍べると, 形態的にこれまで報告 されていない新しい特徴をるっている.たと えば写真に示したように, 繊維状菌体に小さ な小胞をもっていることや，ときどき菌体が

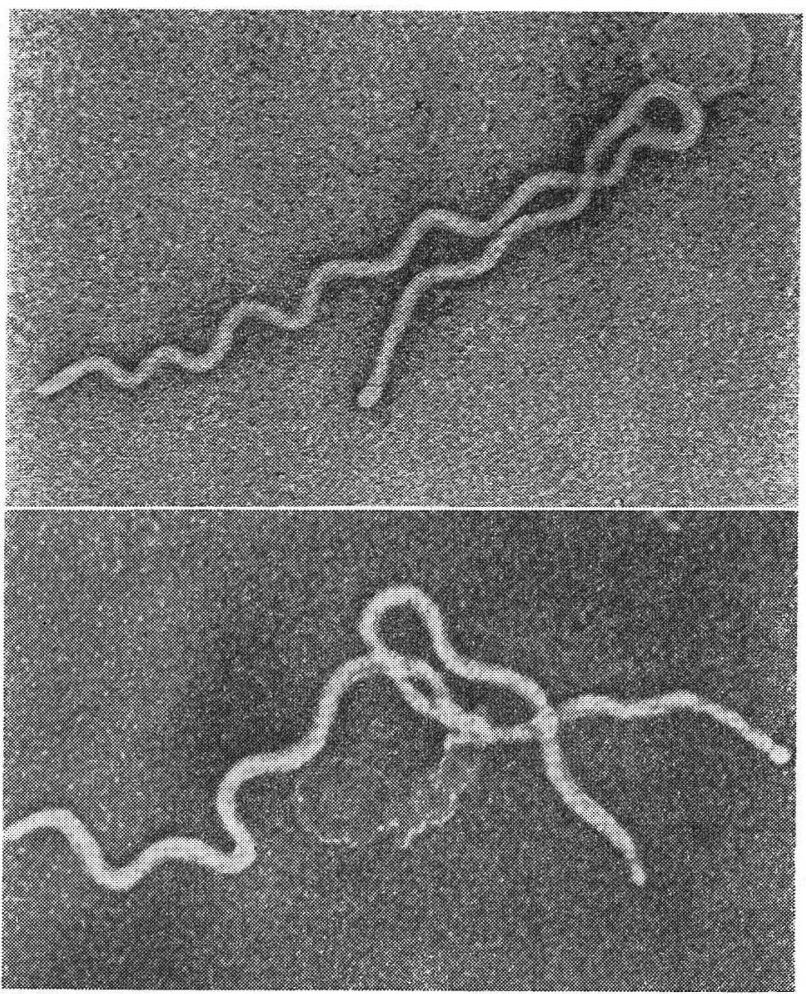

ショウジョウバェの雄を殺す SR 因子の電子顕微鏡写真.

上 : D. willistoni SR 雌の体内で発見されたスピロへ...多栐 SR 因子. PTA によるネガティブ染色. $\times 14,400$.

下:D. nebulosa SR 雌の体内で発見されたスピロへータ承 SR 因子. PTA によるネガティブ染色. ×16,000.
維微生物はスピロヘータのまったく新しい属とすべきか もしれないが，分類学的にはさらに詳細な検討を必要と のる。な拉，この微生物はこれまでに人工培養の試みが なされたが，まだ成功していない。

この微生物をとりだし，これをもたない正常のハエに 注射すると, この微生物は宿主体内で増殖し, それが卵 の中に入って後代に伝わり, 雄胚子のみを選択的に殺す. すなわち，SR 因子と呼んでいる雄を殺す犯人は，この スピロヘータ様微生物であることがわかった。 しかし， このよらなスピロヘータ様の SR 因子は, 日本産 bifasciata 種や米国産 robusta 種の SR 系統のハェの体内 飞はみら机ない。これらの SR 因子は現在のところ人為 的感染が困難であり，またその本態も不明である.

ところで, スピロへータ様の SR 因子に起原のちがう 3 種類のあることは前述した. これらのうら，いずれか 2 種を同一宿主に混合感染させると, 互いに作用し合っ て，小さなコロニーを体液中に多く作るが，しだいにこ のコロニーは消失し，いったん SR 因子が宿主の体液中
に見えなくなり，その後，再びいずれか一方が現われ る. すなわち, 一方の SR 因子は他方の因子を不活化し てしまう。たと党ば, willistoni $(w)$-SR 因子とnebulosa (n)-SR 因子との間では後者が前者を不活化する.また， equinoxialis (e)-SR 因子は前 2 者によって不活化され る.な拉これらの起原の異なる SR 因子のいずれか 2 種類をハェの体外にとり出し，スライド上で混合しても， コロニーが形成される. この機構については現在検討中 であるが，w-SR や $n-\mathrm{SR}$ 因子はそれぞれいくぶん異 なる蛋白性不活化物質を産生して他の因子作用するら しい. 筆者らはこの物質を Spirocin と呼んで, このも のの精製を試み，またその性質などを調べている．起原 のちがうSR 因子の間で形態的にはほとんど区別がつき にくく，また宿主の雄を殺す点に沶いても，同じスピ口 ヘータ様 SR 因子の間でこのような機能的なちがいの ることは興味深い.

SR 因子の働きで重要な問題は, 宿主ハエの雄㖉子の 選択的致死機構であろう。責伝学的立場からみスンシウ 
ジョウバェの雌雄性の決定は, ふつう性染色体構成が $\mathrm{XX}$ のとき雌で，XY のとき雄となる，そこで， SR 因 子の作用とY染色体の役割との関連が当然考兄られる. ショウジョウバェには 2 本のX染色体が一端で付着した 系統があり, この系統に SR 因子を感染させ, その後代 から得られる $\overline{X X Y}$ 型雌に対する SR 因子の作用を調 べたが，この雌は SR 因子に殺されない。このことから， SR 因子の作用はY 染色体の機構と直接の関連がないこ とがわかった。また，SR 因子は XO 型雄を殺し，XX

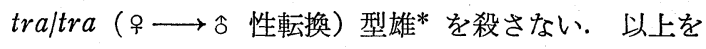
総合すると，SR 因子の作用はショウジョウバェの表現 型が雌雄の如何にかかわらず，X染色体を 1 本もつか, 2 本もつかルよって異なり，それが 1 本のときのみ発現 されて，その個体を殺してしまうことがわかる．SR 因 子の作用と宿主の性染色体構成との関係はほ注明らかに することができたが，乙かしながら，この両者の機能的 な関連に対する生化学的解析は今後に残された重要な問 題である. われわれは現在, この問題に関連して, SR 因子の增殖機構, ならびにこの因子の增殖にともなって 引き起こされる宿主雄肧子の代謝的变化を追跡してい る.

以上, ショジョウバェの雄を殺す SR 因子について概 説したが，前述したように，この因子は人為的に正常の 八エに感染させ，それをSR の特性をもった八土に变え ることができる. しかも，このようにして人為的作っ た SR のハエは, 宿主の遺伝子構成が SR 因子の增殖に 好都合であれば，この SR 因子がハエの後代に伝光ら れ, 遺伝的に SR 系統が確立する.ここで, SR 因子, とくにスピローータ様微生物は遺伝単位とみなされるか という問題がある. この問題に答えるためには, 従来か ら知られている各種微生物, あるいは高等生物の細胞質 遺伝単位（これを染色体外遺伝単位と呼んだほうがよい かもしれない）の特性に触れる必要があろう.

細胞質遺伝単位の 1 つの特徴は, 染色体上の遺伝子之 は独立に, あるいはある程度の支配を受けつつ自己增殖 をし，子孫に伝えられる．また，細胞質遺伝単位の多く の場合は他の細胞に感染し，ときとして，その冲で増殖 し，そこで新しい遺伝的な系を確立する。たとえば，細 菌のいわゆるエピゾームと呼ばれる一群の粒子, すなわ ら性決定因子の F, 多剂耐性の R因子, コリシン因子,

* 性染色体構成が XX では本来雌となるが，第 III 染色体上 にある劣性因子の transformer（tra）と呼ばれる遣伝子 がホモ, すなわち traltraになると, 性転換を起こして 雄型となる. しかし, この個体は不稔性で精子を作らな W.
溶原ファージは, 前記の特徴をもっている.これらのエ. ピゾームは，ときに細菌の染色体に乗り移り，その染色 体と行動をともにするといら特徴も知られているが, こ の特徴は他の細胞質遺伝の単位にはみられない。また， 細胞質遺伝の有名な例として知られているジウリムシの キラー系統（感受性系統のゾウリムシを殺す）にみられ るカッパ粒子, ラムダ粒子, ミュ一粒子などは, 染色体 遺伝子の支配をある程度受けながら, 半独立的に自己増 殖をし，それをるたないジウリムシに感染する. とくに ラムダ粒子は, 試験管内の培養が可能であり, この人工 培養の粒子を再びジウリムシに感染させて細胞質遺伝の 単位とすることができる.さらに, ショウジョウバェの 細胞質遺伝をする $\mathrm{CO}_{2}$ 感受性は, シグマと呼ばれる一 種のウイルスの感染によって引き起こされる系統であり， これも人為的に $\mathrm{CO}_{2}$ 抵抗性の正常のハエに感染させ, それを遺伝的 $\mathrm{CO}_{2}$ 感受性系統にすることができる。一 方, 生体の代謝に重要な役割をむつ細胞の構成要素であ り, また細胞質遺伝単位として知られているミトコンド リアや色素体には, 染色体 DNA とは異なる塩基組成を るつ自己增殖性の DNA が証明され, 最近ミトコンドリ アに执いては細菌やウイルスにみられるよらな環状 DNA が電子顕微鏡によって観察されている.

このように細胞質遺伝因子の特徴を通覽すると, その 本態がかなり独立した 1 個の機能構造体と考えられ，ま た寄生あるいは共生生物とるみなされる場合も多い。こ のような観点からみると，ここで述べた SR 因子の場合 も，宿主の遺伝的に決定される雄性を特異的に殺す点は。 めたかも染色体に存在する致死因子と似た作用をし，乙 か子感染して後代に伝えられてゆく点などから，一種の 細胞質遺伝単位とみなされよう. 感染性の因子によって 遺伝現象が確立してゆくことを感染遺伝 (infectious. heredity）と呼び，この方面の解析は微生物でかなりく わしくなされているが, 高等生物では今後に残された問 題点が多い. SR 因子の研究は, 宿主の遺伝子構成が SR 因子の增殖性を支配する点, SR 因子自体に各種の 遺伝的変異種がみられる点などから, SR 因子自体の遺 伝物質と宿主の遺伝物質との関連性についての生化学的 アプローチと相まって, 今後に物ける高等生物の感染遺 伝現象の解明に好都合な対象である. 一方, SR 因子は 宿主のまだ雌雄の形態的分化が起こらない時期の雄接合 体を選択的に殺すことから，この因子の作用機構を明ら かにすることによって，生物学の基本問題の1つである 性の初期分化を, 生化学的に解明することが可能である 5. 